\title{
EFFECT OF IRRIGATION WATER SALINITY ON SOME SOIL PROPERTIES AND SUGAR BEET YIELD IN NORTH NILE DELTA.
}

Eid, S. M. ; S. A. El-Saady and M. M. Ewis

Soils, Water \& Environment Research Institute (SWERI), Agricultural Research Center (ARC), Egypt.

\begin{abstract}
Sugar beet (Beta Vulgaris L) plant was grown in two field experiments to investigate the effect of irrigation with high and moderately saline waters and irrigation intervals on soil properties and yield of sugar beet crop during 2006/2007 and 2007/2008 at El- Hamoul region, Kafr El Sheikh Governorate. Main plots were assigned to irrigation intervals i.e. two, three and four weeks, $\left(I_{1}, I_{2}\right.$ and $I_{3}$ respectively), while subplots were irrigated with fresh water $S_{1}\left(0.5 \mathrm{dSm}^{-1}\right)$, mixed water $\mathrm{S}_{2}\left(1.8 \mathrm{dSm}^{-1}\right)$ and drainage water $\mathrm{S}_{3}\left(3.8 \mathrm{dSm}^{-1}\right)$ during the whole season except planting irrigation which irrigated with fresh water for all subplots.

Results showed that treatment $\left(I_{1} S_{1}\right)$, irrigation every two weeks with fresh water produced the highest sugar beet yield to be 27.03 ton/Fed while treatment $\left(I_{3}\right.$ $\mathrm{S}_{3}$ ) irrigation every four weeks with drainage water produced the lowest yield (18.37 ton/ Fed). Irrigation every four weeks with fresh water $\left(I_{3} S_{1}\right)$ gave the highest sugar percent to be $19.3 \%$ while irrigation every two weeks with drainage water $\left(I_{1} S_{3}\right)$ gave the lowest sugar percent $(13.2 \%)$. Irrigation every two weeks with fresh water $\left(I_{1} S_{1}\right)$ reduced the soil salinity by $18.8 \%$ after the first season and $30 \%$ after the second season. While irrigation every four weeks with drainage water $3.8 \mathrm{dSm}^{-1} \quad\left(\begin{array}{ll}I_{3} & \mathrm{~S}_{3}\end{array}\right)$ reduced soil salinity by $2 \%$ and $9.5 \% \mathrm{dSm}^{-1}$ after the first and second seasons respectively. Also, the results showed that values of bulk density increased with increasing salinity levels of irrigation water and irrigation intervals in both surface and subsurface soil layers. The lowest values were found in surface soil $(0-15 \mathrm{~cm})$, ranged from 1.09 to $1.23 \mathrm{Mg} \mathrm{m}^{-3}$, while the highest values were found in subsurface soil, (45$60 \mathrm{~cm}$ ) and ranged from 1.24 to $1.30 \mathrm{Mg} \mathrm{m}^{-3}$.

Generally, Irrigation with saline water decreases soil salinity as long as the salt levels in the water are less than that of the soil. This means that with using drainage or mixed water with salts levels of $\left(0.5,1.8,3.8 \mathrm{dSm}^{-1}\right)$ the soil salinity decreased.

Keywords: Irrigation water salinity, sugar beet yield, soil Salinity.
\end{abstract}

\section{INTRODUCTION}

Agriculture in Egypt depends mainly on irrigation from the River Nile (55.5 X 109) m3/year. The need to provide additional land to increase food production compels the farmers to use all sources of water. Therefore, the use of low quality water, such as ground, drainage, reclaimed waste, and even diluted sea water, should be considered as complementary sources, for the expansion of irrigated agriculture and agricultural development.

Salinity is an important index of low soil quality reducing crop production and gradually decreases the area under cultivation. Irrigated agriculture using saline water in the arid and semi-arid region can led to salt accumulation in soil profile, reduction in yield and deterioration in soil resource, if proper management practices are not adapted (Ould et al.,2007). 
To prevent yield loss, soil salinity must be controlled at a concentration level below which might affect the yield (Ayers and Westcot, 1985). Using poor quality irrigation groundwater has become unavoidable to compensate rapidly increasing water demands of competition between human and industrial water use, especially in arid and semi-arid regions (Katerji et al., 2000). To resolve this, researchers recommended methods such as use of fresh water at the initial stage of plant growth, mixing agricultural drainage water with good quality irrigation water, plant breeding (developing salt tolerant cultivars) and alternating good quality irrigation water with saline water Abdel Gawad and Ghaibeh, 2001; Yurtseven et al., 2005; Feizi 2003, and 2004.

Soil salinity is a major environmental factor limiting the productivity of agricultural lands. Soil salinity causes land degradation and affects food production (Sharma \& Rao, 1998). This problem is not only reducing the agricultural productivity, but also putting far reaching impacts on the livelihood strategies of small farmers (Tanwir et al., 2003). During the last 3 - 4 decades due to increased demand for food, the use of irrigation has increased by about $300 \%$. Due to scarcity of surface water resources especially in arid and semi-arid region for supplying irrigation water for agricultural lands, the excessive discharge of the ground water with low quality has occurred, which has imposed a further increase in soil salinization (Poustini \& Siosemardeh, 2004) Overcoming soil salinity and sodicity in arid and semi-arid regions can be achieved by managing water resources, cultivating salt tolerant plants and using leaching with appropriate drainage system. The quality and quantity of water needed to leach soluble salts is an important factor governing reclamation of saline soils. Several researchers believe that appropriate leaching level is related to salinity of drainage water (Hoffman et al., 1979). Researchers found that the best estimation for leaching level for soil desalinization can be made based on soil depth and if the ratio of leaching to soil depth becomes 1 , eventually $87 \%$ of salts will be discharged from the soil and this occurs when the water used for leaching has a low salinity (Khosla et al.,1979). Several studies report that the first leaching is most effective to soil desalinization as compared to the other leaching and using the same level of leaching for long period; soil salinity will continue to rise (Feizi, 1993; ElSayed et al., 2001). Because of high evapotranspiration demand, low annual rainfall, limitation of fresh river water and use of saline and drainage water for irrigation, the soils have lost their productivity due to salinity problems. in EI Hamowl, Kafr El-sheikh Governorate region. Considering the fact that leaching is the most effective and practical method for improvement of saline sodic soils, this study was undertaken to: a) determine the effect of different irrigation water salinity levels on some soil chemical properties and, b) compare the changes in soil chemical properties between the end and beginning of a growing season in order to have better strategies for irrigating arid region soils. One of the main objectives of this paper was to study the relation between irrigation water quality and soil properties on crop yield in order to recommend suitable cropping patterns that can be adopted according to the quality of drainage water, physical and chemical properties of the saline clay soil at El-Hamoul, Kafer El-Sheikh governorate, Egypt. 


\section{MATERIALS AND METHODS}

Site:

Two field experiments were conducted during the two growing seasons 2006/2007 and 2007/2008 at El Hamoul, Kafr El-sheikh Governorate. The site represents the circumstances and conditions of North Nile Delta region and allocated at 31-07' N Latitude, 30-57'E Longitude with an elevation of about 6 meters above sea level. Map (1) illustrates the location of the monitoring area.

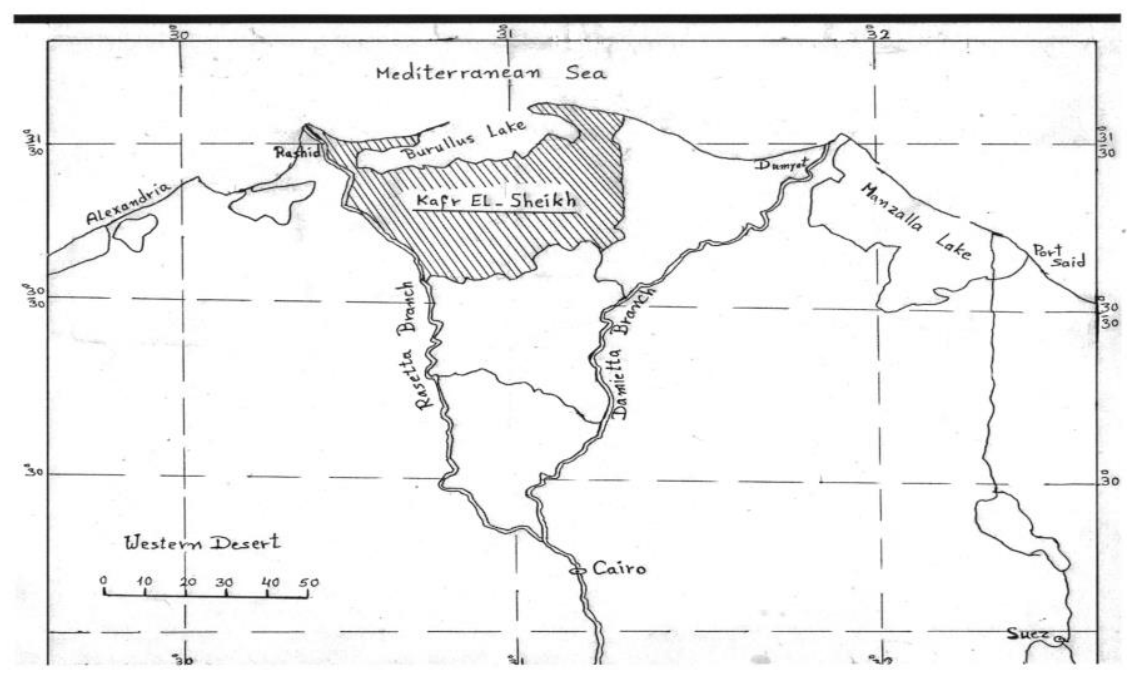

Map 1: Location of the monitoring area (El Hamoul, Kafr El-sheikh)

The experimental site is located near to a main open drain and served by a tile drainage system. Soil of experimental field was clayey in texture $(51.9 \%$ clay, $19.47 \%$ silt and $28.63 \%$ sand) and had $\mathrm{pH} 8.2$ and, ECe10.1dsm-1. Some physical and chemical properties of the experimental soil are presented in Table (1)

Table (1): Average values of some physical and chemical properties of soil under consideration.

\begin{tabular}{|c|c|c|c|c|c|c|c|c|c|c|c|c|}
\hline \multirow[b]{2}{*}{$\begin{array}{c}\text { Soil } \\
\text { depth }\end{array}$} & \multicolumn{3}{|c|}{$\begin{array}{c}\text { Particle size } \\
\text { distribution\% }\end{array}$} & \multirow[b]{2}{*}{ 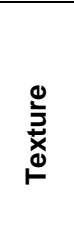 } & \multirow[b]{2}{*}{ FC\% } & \multirow[b]{2}{*}{ WP\% } & \multirow[b]{2}{*}{ AW\% } & \multirow[b]{2}{*}{$\begin{array}{c}\mathrm{Bd} \\
\mathrm{Mgm}^{-3}\end{array}$} & \multirow[b]{2}{*}{$\begin{array}{c}\mathrm{pH} \\
(1-2.5)\end{array}$} & \multirow{2}{*}{ 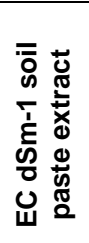 } & \multirow[b]{2}{*}{ SAR } & \multirow[b]{2}{*}{$\begin{array}{c}\mathrm{Caco}_{3} \\
\%\end{array}$} \\
\hline & 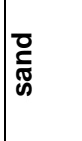 & एँ & $\frac{\sqrt{0}}{0}$ & & & & & & & & & \\
\hline $0-60$ & 28.63 & 19.47 & 51.90 & clayey & 41.3 & 21.8 & 19.5 & 1.19 & 8.2 & 10.1 & 8.12 & 2.74 \\
\hline
\end{tabular}




\section{Eid, S. M. et al.}

\section{Experimental layout:}

Three irrigation water quality were used, fresh water $S_{1}\left(0.5 \mathrm{dSm}^{-1}\right)$; mixed water $S_{2}\left(1.8 \mathrm{dSm}^{-1}\right)$ and drainage water $S_{3}\left(3.8 \mathrm{dSm}^{-1}\right)$ under irrigation intervals i.e. two, three and four weeks, $\left(I_{1}, I_{2}\right.$ and $\left.I_{3}\right)$, Chemical composition of the water used for irrigation are given in Table (2)

Table (2): Chemical composition of the water used for irrigation.

\begin{tabular}{|c|c|c|c|c|c|c|c|c|c|c|c|}
\hline \multirow{2}{*}{$\begin{array}{l}\text { Water source for } \\
\text { irrigation }\end{array}$} & \multirow[b]{2}{*}{ PH } & \multirow{2}{*}{$\begin{array}{l}E C e \\
\mathrm{dSm}^{-1}\end{array}$} & \multirow[b]{2}{*}{ SAR } & \multicolumn{8}{|c|}{ Soluble cations and Anions (meq/L) } \\
\hline & & & & $\mathrm{Na}^{+}$ & $\mathrm{Ca}^{++}$ & $\mathbf{M g}^{++}$ & $\mathrm{K}^{+}$ & $\mathrm{Cl}^{-}$ & $\mathrm{Co}_{3}^{-}$ & $\mathrm{HCO}_{3}{ }^{-}$ & $\mathrm{So}_{4}=$ \\
\hline $\mathrm{S}_{1}$ (fresh v & 8.36 & 0.5 & 3.60 & 3.5 & 0.8 & 1.1 & 0.1 & 2.5 & 0.0 & 2.5 & 0.5 \\
\hline & 7.75 & 1.8 & 6.60 & 12.2 & 2.9 & 4.0 & 0.2 & 8.6 & 0.0 & 5.5 & 5.2 \\
\hline $\mathrm{S}_{3}$ (drainage water) & 7.88 & 3.8 & 9.73 & 25.4 & 5.9 & 7.7 & 0.3 & 17.2 & 0.0 & 6.04 & 16.06 \\
\hline
\end{tabular}

\section{Statistical Analysis}

The experimental design was a split plot design with four replicates as follows:-

I-Main treatments (irrigations intervals) $l_{1}=$ irrigation every 2 weaks; $\mathrm{I}_{2}=$ irrigation every 3 weaks and $\mathrm{I}_{3}$ =irrigation every 4 weeks.

II-Sub treatments (Three irrigation water quality), $S_{1}, S_{2}$ and $S_{3}$ (fresh, mixed and drainage)

Seeds of sugar beet (Beta Vulgaris L.)obtained from Delta sugar Company Limited at Kafr El-Schiekh were seeded in hills at November 3rd, and 5th in two successive seasons 2006/2007 and 2007/2008, respectively and harvested after 190 days. The distance between ridges was $70 \mathrm{~cm}$ and the seeds were sown at $20 \mathrm{~cm}$ between hills within the ridge. Plot area was $52.5 \mathrm{~m}^{2}=1 / 80$ fed .All agricultural practices were done as recommended by the Egyptian Ministry of Agricultural and Land Reclamation.

The data were analyzed using split plot design. The Duncan's multiple range tests was used to make comparisons between treatments according to Duncan (1955).

Yield (ton/fed)

The yield of the two central furrows was weighed and computed as:

(a) Root yield (ton/fed.). (b) Sugar yield (ton/fed.) were obtained by multiplying root yield by sucrose percentage which measured at Delta sugar Company Limited Laboratories at Kafr El-Schiekh

Chemical analysis of soil:-

Electrical Conductivity EC $\left(\mathrm{dSm}^{-1}\right)$ at $25^{\circ} \mathrm{C}$, and soluble cations and Anions were determined in soil paste extract for soils according to page (1982)

\section{Bulk Density}

Bulk density was calculated according to Okalebo et al. (1993)

\section{RESULTS AND DISCUSSION}

\section{Roots and sugar yield:}

Data in Table (3) show that irrigation intervals and water salinity affected sugar beet production. Roots and sugar yield were significantly 
decreased as irrigation intervals and water salinity increased. The highest values of roots and sugar yield 25.11 and 3.88 ton/fed, respectively were achieved under $\left(\mathrm{I}_{1}\right)$ treatment. The lowest values of roots and sugar yield 20.46 and 3.45 ton /fed, respectively were obtained under $\left(I_{3}\right)$ treatment. Increasing irrigation intervals from 2 to 4 weeks decreased root and sugar yield by 18.5 and $11.1 \%$, respectively.

Concerning water salinity, the highest values of roots and sugar yield 25.54 and 4.76 ton/ fed, respectively were produced under water irrigation $\left(S_{1}\right.$ $\left.0.5 \mathrm{dSm}^{-1}\right)$ while irrigation with drainage water $\left(\mathrm{S}_{3}, 3.8 \mathrm{dSm}^{-1}\right)$ decreased root and sugar yield by about 21 and $42 \%$ respectively compared to fresh water irrigation. Reduction in sugar beet production was more pronounced with increasing water salinity than that of increasing irrigation intervals.

Concerning the interaction between irrigation intervals and water salinity, the highest values of roots yield $27.03 \mathrm{ton} /$ fed was obtained under $I_{1} S_{1}$, and that of sugar yield 4.99 ton/fed was achieved under $\mathrm{I}_{2} \mathrm{~S}_{1}$, while the lowest values of roots and sugar yield 18.37 and 2.57 ton/fed, respectively were obtained under $\left(\mathrm{I}_{3} \mathrm{~S}_{3}\right)$.

Irrigation every 2-3 weeks with fresh water $\left(0.5 \mathrm{dSm}^{-1}\right)$ had the maximum sugar beet yield, and irrigation with drainage water every 4 weeks had the lowest yield .Irrigation with drainage water every 2 weeks, treatment $\mathrm{I}_{1} \mathrm{~S}_{3}$ had an acceptable yield of about 22.12 and 2.90 ton/fed for roots and sugar yield, respectively. This indicate that irrigation at short intervals could compensate partially the hazards effect of the water salinity on crop yield. The obtained yield by treatments $I_{1} S_{3}$ is about $80 \%$ and $59 \%$ for roots and sugar yield, respectively, relative to the yield obtained by the treatment $I_{1} S_{1}$. Similar results were obtained by Ibrahim et al,(1995), who showed that the maximum yield of roots and sugar yield 25.1 and 3.99 ton/fed , respectively were obtained from treatment had $6 \mathrm{~cm}$ depth of water every two weeks in shallow water table in the same area of the current study. Also, these results are in harmony with those published by several authors concerning the effect of salinity on sugar beet yield ,(El-Etreiby,2000). According to the above illustrated results and discussion, drainage water $\left(3.8 \mathrm{dSm}^{-1}\right)$ can be used to irrigate sugar beet at two weeks interval, under the condition of the current study, to obtain an acceptable yield.

Table (3): Effect of irrigation intervals and irrigation water salinity on root yield (ton/fed) and sugar yield (Ton/fed) of sugar beet, as combined analysis of the two growing seasons.

\begin{tabular}{|c|c|c|c|c|c|c|c|c|}
\hline \multirow{2}{*}{ Treatments } & \multicolumn{4}{|c|}{ Root yield (Ton//fed) } & \multicolumn{4}{c|}{ Sugar yield (Ton//fed) } \\
\cline { 2 - 9 } & $\mathbf{S}_{1}$ & $\mathbf{S}_{\mathbf{2}}$ & $\mathbf{S}_{3}$ & Mean & $\mathbf{S}_{1}$ & $\mathbf{S}_{2}$ & $\mathbf{S}_{3}$ & Mean \\
\hline $\mathbf{l}_{\mathbf{1}}$ (2 weeks) & $27.03 \mathrm{a}$ & $25.38 \mathrm{a}$ & $22.12 \mathrm{a}$ & 25.11 & $4.94 \mathrm{a}$ & $3.81 \mathrm{a}$ & $2.90 \mathrm{a}$ & $3.88 \mathrm{a}$ \\
$\mathbf{I}_{\mathbf{2}}$ (3 weeks) & $26.18 \mathrm{~b}$ & $21.98 \mathrm{~b}$ & $20.15 \mathrm{~b}$ & 22.77 & $4.99 \mathrm{a}$ & $3.52 \mathrm{~b}$ & $2.82 \mathrm{a}$ & $3.78 \mathrm{~b}$ \\
$\mathbf{I}_{\mathbf{3}}$ (4 weeks) & $22.60 \mathrm{c}$ & $20.42 \mathrm{c}$ & $18.37 \mathrm{c}$ & 20.46 & $4.36 \mathrm{~b}$ & $3.43 \mathrm{~b}$ & $2.57 \mathrm{~b}$ & $3.45 \mathrm{c}$ \\
\hline Mean & 25.54 & 22.59 & 20.21 & & 4.76 & 3.58 & 2.76 & \\
\hline
\end{tabular}

Means designated by the same letter at each cell are not significant at the $5 \%$ level according to Duncan's

Multiple range tests

$\begin{array}{llclc}\text { Comparison } & \text { LSD }(5 \%) & \text { LSD }(1 \%) & \text { LSD }(5 \%) & \text { L SD(1\%) } \\ \text { In row } & 0.444 & 0.610 & 0.113 & 0.155 \\ \text { In column } & 0.435 & 0.586 & 0.109 & 0.149\end{array}$




\section{Eid, S. M. et al.}

\section{Electrical Conductivity EC (dSm-1)}

The obtained results in Table (4) and Fig (1) indicate that the EC value decreased after the first season from 10.1 to $\left(8.2,9.04,9.54 \mathrm{dSm}^{-1}\right.$ ); $(8.44,9.14,9.24)$ and $(8.56,9.76,9.88)$ when the sugar beet was irrigated with water has $0.5,1.8,3.8 \mathrm{dSm}^{-1}$ under frequently 2,3 , and 4 weeks respectively. The irrigation water move downwards carrying the dissolved salts from the upper layer to the lower one. Again the pores of this layer are filled and the water moves to a lower layer and so on. Also the effect of the water salinity, showed that irrigation with fresh water $I_{1} S_{1}$ treatment $(0.5$ $\left.\mathrm{dSm}^{-1}\right)$, achieved the highest soil salinity reduction $(30 \%)$, while the lowest soil salinity reduction $(9.5 \%)$, were obtained under $\mathrm{I}_{3} \mathrm{~S}_{3}$ treatment $\left(3.8 \mathrm{dSm}^{-1}\right)$.

Table (4): Soil electric conductivity (ECe) as affected by irrigation intervals and irrigation water salinity after harvesting of sugar beet.

\begin{tabular}{|c|c|c|c|c|c|c|c|c|}
\hline \multicolumn{2}{|c|}{ Treatments } & \multirow{2}{*}{$\begin{array}{c}\text { Before } \\
\text { experiment }\end{array}$} & \multirow{2}{*}{$\begin{array}{c}\text { After } \\
\text { harvest } \\
\text { the } 1^{\text {st }} \\
\text { season }\end{array}$} & \multirow[b]{2}{*}{$\begin{array}{l}\text { Rate of } \\
\text { change }\end{array}$} & \multirow[t]{2}{*}{$\%$} & \multirow{2}{*}{$\begin{array}{c}\text { After } \\
\text { harvest } \\
\text { the } 2^{\text {nd }} \\
\text { season }\end{array}$} & \multirow[b]{2}{*}{$\begin{array}{l}\text { Rate of } \\
\text { change }\end{array}$} & \multirow[b]{2}{*}{$\%$} \\
\hline $\begin{array}{l}\text { Irrigation } \\
\text { interval }\end{array}$ & $\begin{array}{c}\text { Quality of } \\
\text { irrigation } \\
\text { water }\end{array}$ & & & & & & & \\
\hline \multirow[t]{3}{*}{$l_{1}(2$ weeks $)$} & $\mathrm{s}_{1}\left(0.5 \mathrm{dSm}^{-1}\right)$ & 10.1 & 8.2 & -1.9 & 18.8 & 7.05 & -3.05 & 30.0 \\
\hline & $\mathrm{s}_{2}\left(1.8 \mathrm{dS} \mathrm{m}^{-1}\right)$ & 10.1 & 9.04 & -1.06 & 10.5 & 7.95 & -2.15 & 20.0 \\
\hline & $\mathrm{s}_{3}\left(3.8 \mathrm{dS} \mathrm{m} \mathrm{m}^{-1}\right)$ & 10.1 & 9.54 & -0.56 & 5.5 & 8.35 & -1.75 & 17.0 \\
\hline \multirow[t]{3}{*}{$\mathrm{l}_{2}$ (3 weeks) } & $\mathrm{s}_{1}\left(0.5 \mathrm{dSm}^{-1}\right)$ & 10.1 & 8.44 & -1.66 & 1.6 & 7.85 & -2.25 & 22.0 \\
\hline & $\mathrm{s}_{2}\left(1.8 \mathrm{dS} \mathrm{m}^{-1}\right)$ & 10.1 & 9.14 & -0.96 & 9.5 & 8.65 & -1.45 & 14.0 \\
\hline & $\mathrm{s}_{3}\left(3.8 \mathrm{dS} \mathrm{m}^{-1}\right)$ & 10.1 & 9.24 & -0.86 & 8.5 & 8.76 & -1.34 & 13.0 \\
\hline \multirow[t]{3}{*}{$I_{3}$ (4 weeks) } & $\mathrm{s}_{1}\left(0.5 \mathrm{dSm}^{-1}\right)$ & 10.1 & 8.56 & -1.54 & 1.5 & 8.45 & -1.65 & 16.0 \\
\hline & $\mathrm{s}_{2}\left(1.8 \mathrm{dS} \mathrm{m}^{-1}\right)$ & 10.1 & 9.76 & -0.34 & 3.0 & 8.76 & -1.34 & 14.0 \\
\hline & $\mathrm{s}_{3}\left(3.8 \mathrm{dS} \mathrm{\textrm {m } ^ { - 1 } )}\right.$ & 10.1 & 9.88 & -0.22 & 2.0 & 9.12 & -0.98 & 9.5 \\
\hline
\end{tabular}

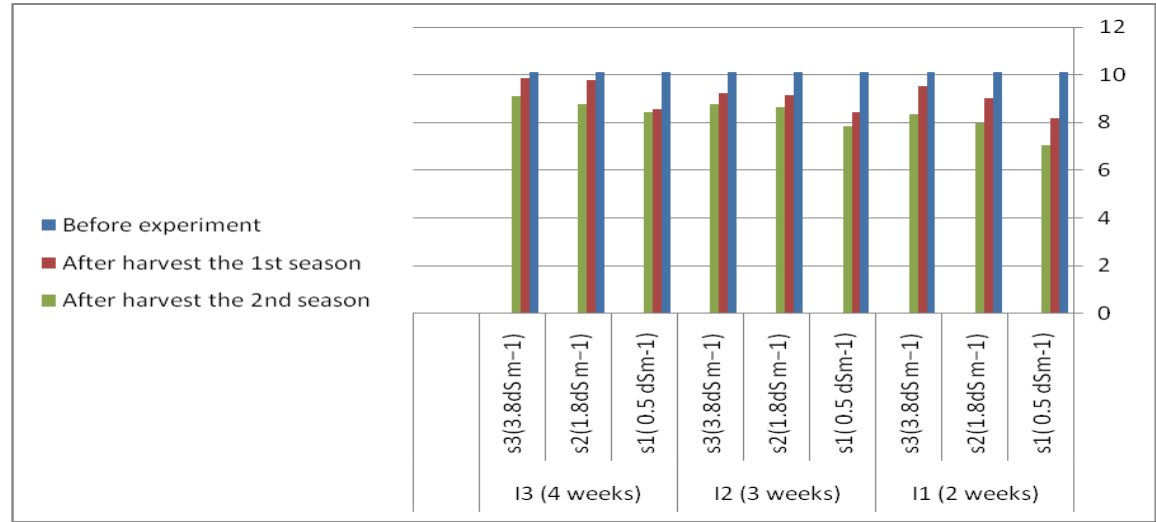

Fig (1): Soil electric conductivity (ECe) as affected by irrigation intervals and irrigation water salinity after harvesting of sugar beet.

\section{Bulk Density}

The effect of different salinity levels of irrigation water on bulk density, after cropping. Data showed that all water salinity levels, which were used, increased the values of the soil bulk density. These increments progressively increased with increasing salinity levels of irrigation 
water.These results may be due to the increase of salts in the irrigation water would progressively increase sodium ion in the soil solution, cause in the dispersion of soil particles which led to increase in soil bulk density. Similar conclusions were reported by Nikos et al, 2003. Individual bulk density values for plots irrigated with fresh water ranged from 1.09 to $1.30 \mathrm{Mg} \mathrm{m}^{-3}$ with consistently lower values in the surface soil. The low bulk density in the surface soil may be due to soil texture, tillage, and organic matter and crop residues. Plots irrigated with medium levels of saline water have similar bulk densities as the high salinity levels of irrigation treatments. While the highest values were found in subsurface soil, ranged from 1.21 to $1.28 \mathrm{Mg} \mathrm{m}^{-3}$, this may be due to natural compaction (Ibrahim and Gaheen 1999) and (Vedprakash et al. 2004). Also the data showed that the values of Bulk density appears to be unaffected by irrigation intervals. Bulk density values are given in Table (5)

Table (5): bulk density values in Mgm-3 as affected by irrigation water salinity and irrigation intervals after harvesting of sugar beet..

\begin{tabular}{|c|c|c|c|c|c|}
\hline \multicolumn{2}{|c|}{ Treatments } & \multicolumn{4}{|c|}{ Depth } \\
\hline $\begin{array}{l}\text { Irrigation } \\
\text { intervals }\end{array}$ & $\begin{array}{c}\text { Quality of } \\
\text { irrigation water }\end{array}$ & $0-15 \mathrm{~cm}$ & $15-30 \mathrm{~cm}$ & $30-45 \mathrm{~cm}$ & $45-60 \mathrm{~cm}$ \\
\hline \multirow[t]{3}{*}{$l_{1}(2$ weeks) } & $\mathrm{s}_{1}\left(0.5 \mathrm{dSm}^{-1}\right)$ & 1.09 & 1.14 & 1.21 & 1.24 \\
\hline & $\mathrm{s}_{2}\left(1.8 \mathrm{dS} \mathrm{m}^{-1}\right)$ & 1.15 & 1.20 & 1.26 & 1.30 \\
\hline & $s_{3}\left(3.8 d S ~ m^{-1}\right)$ & 1.20 & 1.24 & 1.28 & 1.30 \\
\hline \multirow[t]{3}{*}{$\mathrm{I}_{2}$ (3 weeks) } & $\mathrm{s}_{1}\left(0.5 \mathrm{dSm}^{-1}\right)$ & 1.12 & 1.19 & 1.26 & 1.30 \\
\hline & $\mathrm{s}_{2}\left(1.8 \mathrm{dS} \mathrm{\textrm {m } ^ { - 1 } )}\right.$ & 1.16 & 1.24 & 1.26 & 1.30 \\
\hline & $\mathrm{s}_{3}\left(3.8 \mathrm{dS} \mathrm{m}^{-1}\right)$ & 1.22 & 1.25 & 1.29 & 1.30 \\
\hline \multirow[t]{3}{*}{$\mathrm{I}_{3}$ (4 weeks) } & $\mathrm{s}_{1}\left(0.5 \mathrm{dSm}^{-1}\right)$ & 1.13 & 1.20 & 1.26 & 1.30 \\
\hline & $\mathrm{s}_{2}\left(1.8 \mathrm{dS} \mathrm{\textrm {m } ^ { - 1 } )}\right.$ & 1.15 & 1.21 & 1.27 & 1.30 \\
\hline & $s_{3}\left(3.8 d S ~ m^{-1}\right)$ & 1.23 & 1.25 & 1.28 & 1.30 \\
\hline
\end{tabular}

\section{Conclusion}

Irrigation with saline water decreases soil salinity as long as the salt concentration in the water is less than that of the soil. Using drainage or mixed water with salts concentrations of $\left(3.8\right.$ and $\left.1.8 \mathrm{dSm}^{-1}\right)$, the soil salinity decreases especially when salinity of soil was higher than $4 \mathrm{dSm}^{-1}$.

Sugar beet can tolerate salinity in irrigation water up to $1.8,3.8 \mathrm{dSm}^{-1}$ when soil salinity was $\left(10.1 \mathrm{dSm}^{-1}\right)$, and the effect was reflected on decreasing the yield, by about $11.5,20.8 \%$ respectively.

\section{REFERENCES}

Abdel Gawad, G;And A. Ghaibeh (2001) Use of low quality water for irrigation in the Middle East. Proc. Symp. Sustainable management of irrigated land for salinity and toxic elements control, US Salinity Laboratory Riverside, California.

Ayers RS, And D.W. Westcot (1985) Water Quality for Agriculture. FAO 29 Rev. 
Eid, S. M. et al.

Duncan, B.D. (1955). Multiple range and multiple F-tests. Biometrics. 11: 142.

El-Etreiby, F. (2000). Effect of saline irrigation water and micronutrient foliar application on sugar beet cultivars. Alex. Sci. Exch. Vol. 21 (4): 397.

El-Sayed, H., El-Haddad and M. N. Maher, (2001). Leaching requirement and salinity threshold for yield and agronomic characteristics of halophytes under salt stress. J. Arid. Enviro., 49:865-74.

Feizi, M. (2003) Water use Efficiency of wheat, barley, cotton and sunflower with respect to water quality. Iranian J. Soil Water Sci. 17(1): 97-105 (In farsi).

Feizi, M. (2004) Effects of saline irrigation water on sunflower yield. Iranian J. Soil Water Sci. 18(2): 179-188 (In farsi).

Feizi, M., (1993) Considering the effect of water quality and quantity on desalinization of Isfahan Roudasht Soils. Technical Research Report,Isfahan Agricultural and Natural Resources Research Center,Isfahan, Iran, 8: 16-34.

Hoffman, G.J., S.L. Rawlins, J.D. Oster, J.A. Jobes and J.D. Merrill, (1979).Leaching requirement for salinity control I. Wheat, sorghum and lettuce. Agric. Water Manag., 2: 177-92

Ibrahim M.A. M.M. Ibrahim, S.A. Gaheen and S.M. Ismail (1995). Role of irrigation Management on water parameters and yield of Sugar Beet in Shallow water Table soils of Nlie delta. Water Resources Management in Arid counturies, Muscat Sultanate of Oman, March 1995., 98-106.

Ibrahim, S.M. and S.A. Gaheen (1999). Improvement of compacted layers of the upper subsoil in a clay soil. Egypt J. of Soil Sci. 39(3): 373-381.

Katerji N, JW .Van Hoorn, A. Hamdy, M. Mastrorilli (2000) Salt tolerance classification of crops according to soil salinity and to water stress day index. J. Agr. Water Manage. 43: 9-109.

Khosla, B.K., R.K. Gupta and I.P. Abrol, (1979). Salt leaching and the effect of gypsum application in a saline-sodic soil. Int. J. Agric. WaterManag., 2: 193-202.

Nikos,j.w., E.P Krista, and W. B James,(2003).The Basics of salinity and sodicity effects on soil physical properties. available at :http://water quality montana.edu/docs/methane/basics highlight.shtml.

Okalebo, J.R., K.W. Gathua and P.L. Woomer, 1993. Laboratory methods of soil and plant analysis: A working manual. TSBF Program, Soil Science Society of East Africa, Technical Publication No. 1, UNESCO,ROSTA, Kenya.

Ould Ahmed BA, T. Yamamoto, M. Inoue (2007) Response of drip irrigated sorghum varieties growing in dune sand to salinity levels in irrigation water. J. Appl. Sci. 7: 1061-1066.

Page, A.I. (1982). Methods of Soil Analysis. Part2 Chemical and Microbiological Properties(2nd ed)Amer. Agron. In Soil Sci . Soc. Amr.Inc.Madison Wisconsin,USA,chpter 12,pp,199-223.

Poustini, K. and A. Siosemardeh, (2004). Ion distribution in wheat cultivars in response to salinity stress. Field Crops Res., 85: 125-33. 
Sharma, D.P. and K.V.G.K. Rao, (1998). Strategy for long term use of saline drainage water for irrigation in semi-arid regions. Soil Tillage Res.,48: 287-95.

Tanwir, F., A. Saboor and N. Nawaz, (2003). Soil salinity and the livelihood strategies of small farmers: A case study in Faisalabad district, Punjab, Pakistan. Int. J. Agric. Biol., 5: 440-1

Vedprakash; Ranjanbhattacharya and Aksrivastva (2004). Effect of tillage management on yield and soil properties under soybean (Glycine max) based cropping system in mid-hills of north-western Himalayas. Indian J. of Agricultural Sci. 74(11): 573-577.

Yurtseven,E.,G.D.Kesmez and A.Unlukara(2005). The effects of water salinity and potassium levels on yield, fruit quality and water consumption of a native central anatolian tomato species (Lycopersicon esculantum). Agricultural Water Management, 78(1 2):128-135.

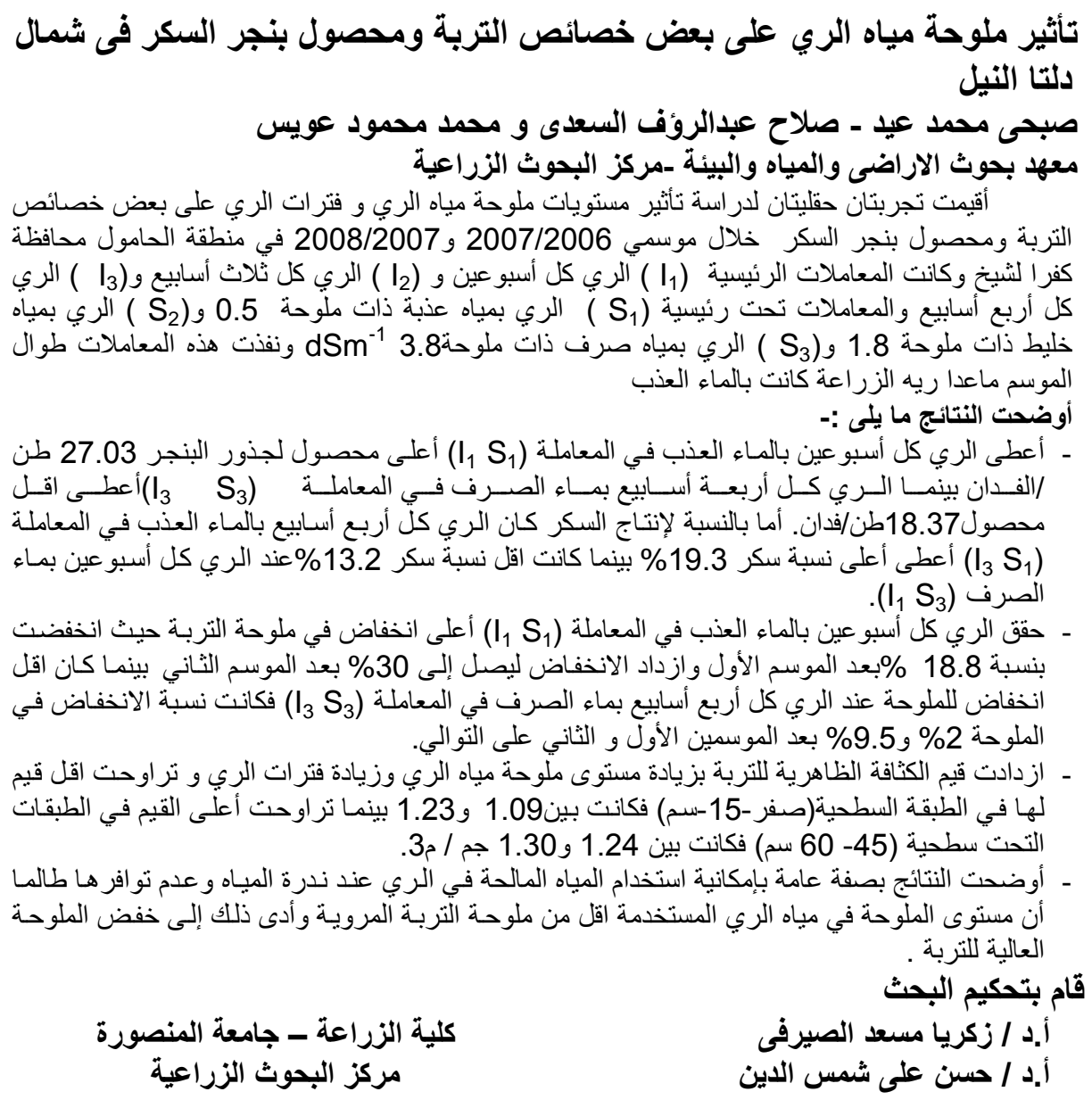


Eid, S. M. et al. 